\title{
PENGARUH KOMPENSASI, MOTIVASI, DISIPLIN KERJA TERHADAP PRODUKTIVITAS KERJA KARYAWAN DIVISI SALES DI HONDA DENPASAR AGUNG
}

\author{
Ni Putu Cindyana Claudia Santoni ${ }^{1}$ \\ I Wayan Suana ${ }^{2}$ \\ ${ }^{1,2}$ Fakultas Ekonomi dan Bisnis Universitas Udayana, Bali, Indonesia \\ e-mail: cindyclaudya27@gmail.com
}

\begin{abstract}
ABSTRAK
Tujuan penelitian ini adalah untuk mengetahui pengaruh kompensasi, motivasi, dan disiplin kerja terhadap produktivitas kerja. Penelitian ini dilakukan pada perusahaan yang bergerak di industri perdagangan otomotif yaitu Honda Denpasar Agung. Jumlah sampel sebanyak 40 orang. Data dikumpulkan melalui wawancara dan kuesioner serta menggunakan teknik analisis regresi linear berganda. Berdasarkan hasil analisis ditemukan bahwa kompensasi berpengaruh positif dan signifikan terhadap produktivitas kerja. Motivasi memiliki pegaruh positif signifikan terhadap produktivitas kerja. Disiplin kerja berpengaruh positif dan signifikan terhadap produktivitas kerja. Kompensasi yang baik diyakini dapat mendorong karyawan untuk bersedia bekerja lebih produktif. Pemberian motivasi akan meningkatkan produktivitas kerja karyawan tersebut. Memperhatikan kedisiplinan karyawan sangat diperlukan karena jika karyawan sudah disiplin dalam bekerja maka karyawan dapat dikatakan produktif.
\end{abstract}

Kata kunci: produktivitas kerja, kompensasi, motivasi, disiplin kerja

\begin{abstract}
The purpose of this study was to determine the effect of compensation, motivation, and discipline on work productivity. This research was conducted in companies engaged in the automotive trade industry is Honda Denpasar Court. The total sample of 40 people. Data were collected through interviews and questionnaires as well as using multiple linear regression analysis. Based on the analysis found that compensation is positive and significant effect on work productivity. Motivation has a significant positive pegaruh to work productivity. Labor discipline and significant positive effect on work productivity. A good compensation is believed to encourage employees to be willing to work more productively. Motivation will increase the productivity of employees. Noting the employee discipline is necessary because if the employee has been disciplined at work, the employee can be said to be productive.

Keywords: work productivity, compensation, motivation, work discipline
\end{abstract}


Ni Putu Cindyana Claudia Santoni, Pengaruh Kompensasi...

\section{PENDAHULUAN}

Keberhasilan organisasi perusahaan tergantung pada produktivitas karyawannya sehingga produktivitas menjadi pertimbangan sangat penting dalam mencapai tujuan organisasi tersebut. sumber daya manusia harus mendapatkan pengkajian yang lebih dalam dan perhatian yang khusus untuk meningkatkan produktivitas kerja yang lebih baik (Hanaysha, 2016). Sumber daya manusia memiliki peranan paling penting di dalam berhasil atau gagalnya organisasi tersebut (Hamali, 2013). Sumber daya manusia dapat dikatakan produktif apabila memiliki produktivitas kerja yang tinggi serta dapat mencapai sasaran atau target yang telah ditentukan dan dapat bertanggung jawab menyelesaikan tugas dengan tepat waktu.

Produktivitas kerja karyawan di pengaruhi oleh beberapa faktor di antaranya menurut (Sutrisno, 2009) yaitu sikap mental adalah konsepsi atau perilaku yang muncul dari jiwa seseorang sebagai reaksi atas situasi yang mempengaruhinya, kemampuan fisik karyawan adalah kemampuan dan kecakapan dalam diri seseorang untuk menyelesaikan suatu kegiatan ataupun tugas, hubungan antara atasan dan bawahan adalah hubungan-hubungan itu diperlihatkan adanya saling ketertarikan secara pribadi, saling percaya, kesetian yang kuat, komunikasi yang nyaman, dan pengaruh yang saling timbal balik. Salah satu Faktor yang menentukan besar kecilnya produktivitas antara lain pengetahuan (knowledge), keterampilan (skills), kemampuan (ambities), sikap (attitudes), perilaku (behaviors). 
Meningkatkan produktivitas kerja karyawan juga dapat dipengaruhi oleh kompensasi, motivasi kerja, dan disiplin kerja. Menurut Ardana dkk. (dalam Rumondor, 2012:270) produktivitas merupakan perbandingan hasil yang diperoleh dengan faktor produksi yang dipergunakan. Jika karyawan memiliki dorongan yang dapat meningkatkan kemampuan dalam meningkatkan produktivitas kerja, dengan kemampuan yang dimiliki tersebut maka tujuan perusahaan akan terlaksana dengan efektif dan efisien (Huzain, 2015).

Arsyad (2014) menyatakan disiplin karyawan adalah salah satu faktor yang dapat meningkatkan produktivitas secara drastis. Disiplin kerja menurut (Nitisemito 2000:199). Disiplin kerja yang baik dapat dilihat dari rasa tanggung jawab yang besar seorang karyawan terhadap pekerjaan yang diberikan kepadanya. Untuk meningkatkan produktivitas kerja dipengaruhi oleh faktor kompensasi.

Kompensasi merupakan segala pendapatan yang berbentuk uang, barang langsung atau tidak langsung sebagai imbalan atas jasa yang diberikan kepada perusahaan terhadap karyawan (Hasibuan, 2003). Faktor lainnya adalah motivasi. Muammam et al. (2013) menyatakan bahwa motivasi sangat diperlukan pada diri seseorang sehingga motivasi adalah salah satu kunci untuk mencapai suatu kebutuhan yang ingin dicapai. Dengan kata lain, timbulnya motivasi pada diri seseorang karena adanya harapan, sasaran, kebutuhan, dorongan, keinginan, serta tujuan. Dorongan bekerja akan timbul pada diri seseorang disebabkan oleh adanya kebutuhan yang harus dipenuhi dan adanya tingkat kebutuhan yang berbeda pada setiap pegawai, sehingga menimbulkan perbedaan motivasi dalam berprestasi. 
Ni Putu Cindyana Claudia Santoni, Pengaruh Kompensasi...

Honda Denpasar Agung suatu organisasi perusahaan yang bergerak di bidang industri perdagangan otomotif. Honda Denpasar Agung terletak di Jl. Hayam Wuruk No. 40 Denpasar-Bali. Perusahaan otomotif Honda Denpasar Agung ini di dirikan pada 25 November 1990. Dalam menjalankan usahanya, Dealer Honda Denpasar Agung ini telah memanfaatkan sumber sumber daya manusia yang baik untuk keberhasilan usahanya. Dealer Honda Denpasar Agung telah memiliki koordinasi agar di masing masing bagian dari perusahaan dapat bekerja dengan baik dan berjalan dengan semestinya. Dalam upaya memenuhi target Dealer Honda Denpasar Agung telah didukung oleh keahlian dan keterampilan dari karyawan agar dapat memberikan pelayanan yang baik tentunya hal tersebut diperlukan produktivitas karyawan yang baik.

Berdasarkan wawancara dengan sales manager pada dealer Honda Denpasar Agung menyatakan di lingkungan industri perusahaan masih terdapat masalah mengenai produktivitas kerja dimana masalah ini terlihat jelas pada karyawan divisi sales yaitu sebanyak 15 persen dari 40 karyawan divisi sales tidak dapat mencapai target penjualan. Selain jumlahnya yang paling banyak diantara divisi lain karyawan bagian penjualan adalah karyawan yang memegang peranan penting didalam menjalankan perusahaan yang bergerak di bidang perdagangan ini.

Dalam Perusahaan Dealer Honda Denpasar Agung terlihat masih sering terjadi keterlambatan dari para karyawan dalam masuk bekerja, adanya sebagian yang tidak tepat waktu dalam menyelesaikan pekerjaannya dan sebagian karyawan masih banyak meninggalkan tugas pada jam kerja tanpa keterangan 
yang sah. Hal tersebut membuat masalah lain dimana penciptaan suatu kondisi yang dapat memberikan kepuasan kebutuhan para karyawan. Kondisi tersebut menimbulkan permasalahan bagi pimpinan untuk memberikan motivasi bagi pekerjanya untuk dapat melaksanakan pekerjaan secara maksimal dengan terus memotivasi dan memberikan kompensasi berupa insentif dan bonus jika masing masing karyawan mampu bekerja sesuai dengan target yang telah ditentukan.

Penelitian sebelumnya yang dilakukan oleh Sis Wartono (2015) tentang "Pengaruh Kompensasi, Motivasi Kerja, Disiplin Kerja Terhadap Produktivitas Kerja Karyawan Pada PT. Dua Putra Utama Makmur Di Kabupaten Pati” yang menghasilkan adanya pengaruh positif dan signifikan antara kompensasi, motivasi, dan disiplin kerja terhadap produktivitas kerja di perusahaan tersebut, dan masih kurangnya penelitian empiris pada produktivitas kerja karyawan di perusahaan bidang industri perdagangan, hal ini menjadi fenomena baru karena sebagian besar penelitian empiris mengenai produktivitas kerja hanya pada perusahaan industri manufaktur. Berdasarkan uraian diatas penelitian ini bertujuan untuk memberikan kontribusi yang positif bagi Dealer Honda Denpasar Agung sekaligus mengetahui bagaimana pengaruh kompensasi, motivasi dan disiplin kerja terhadap produktivitas kerja karyawan pada perusahaan industri perdagangan khususnya.

Rumusan masalah penelitian ini adalah sebagai berikut: (a) Bagaimana pengaruh kompensasi terhadap produktivitas kerja karyawan pada Honda Denpasar Agung?; (b) Bagaimana pengaruh motivasi terhadap produktivitas kerja karyawan pada Honda Denpasar Agung?; (c) Bagaimana pengaruh disiplin kerja 
Ni Putu Cindyana Claudia Santoni, Pengaruh Kompensasi...

terhadap produktivitas kerja karyawan pada Honda Denpasar Agung. Berdasarkan rumusan masalah maka tujuan penelitian ini adalah (a) Menganalisis pengaruh kompensasi terhadap produktivitas kerja karyawan Honda Denpasar Agung; (b) Menganalisis pengaruh motivasi terhadap produktivitas kerja karyawan Honda Denpasar Agung; (c) Menganalisis pengaruh disiplin kerja terhadap produktivitas kerja karyawan Honda Denpasar Agung.

Beberapa manfaat dari penelitian ini adalah (a) Manfaat teoritis yaitu diharapkan penelitian ini dapat digunakan sebagai bahan dalam menambah pengetahuan dan wawasan serta referensi dalam menambah informasi; (b) Manfaat praktis yaitu penelitian ini diharapkan dapat menjadi gambaran dan referensi bagi Honda Denpasar Agung Bali, sebagai bahan pertimbangan dan saran yang membangun dalam pemahaman tentang pengaruh kompensasi, motivasi dan disiplin kerja terhadap produktivitas kerja karyawan.

Salah satu teori yang mendasari penelitian ini adalah yang dikembangkan oleh Abraham Maslow mengemukakan teori motivasi yaitu Maslow's Needs Hierarchy Theory/A Theory of Human Motivation atau teori Motivasi Hierarki kebutuhan Maslow. Teori ini menyatakan bhwa hierarki kebutuhan mengikuti teori jamak, yaitu seseorang berperilaku dan bekerja, karena adanya dorongan untuk memenuhi berbagai macam kebutuhan. Maslow berpendapat, kebutuhan yang diinginkan seseorang itu berjenjang, artinya jika kebutuhan yang pertama telah terpenuhi, kebutuhan tingkat kedua telah terpenuhi, muncul kebutuhan tingkat ketiga dan seterusnya sampai tingkat kebutuhan kelima. 
Klingner dan Nalbaldian (dalam Gomes 2003:160) menyatakan bahwa produktivitas merupakan fungsi perkalian dari usaha pegawai, yang didukung dengan motivasi yang tinggi, dengan kemampuan pegawai, yang diperoleh melalui latihan-latihan. Hanaysha (2016) menjelaskan produktivitas merupakan aspek penting didalam perusahaan untuk membangun organisasi yang memiliki daya saing di dalam mencapai tujuan perusahaan. Elqadri et al. (2013) menyatakan bahwa produktivitas umumnya sebagai hubungan antara output (barang atau jasa) dan input (tenaga kerja, bahan, uang). Produktivitas adalah ukuran efisiensi yang produktif. Beberapa faktor yang mempengaruhi produktivitas kerja yaitu pendidikan, motivasi, kompensasi yang baik, etos kerja, keterampilan, lingkungan dan iklim kerja, disiplin kerja yang keras, sarana dan teknologi yang baik, manajemen yang baik serta kesempatan untuk berprestasi (Anoraga, 2007:240). Simamora (2004:612) menjelaskan faktor-faktor yang digunakan dalam pengukuran produktivitas yaitu kuantitas kerja, kualitas kerja dan ketepatan waktu.

Kompensasi merupakan salah satu kebijakan organisasi perusahaan yang berpengaruh terhadap semangat kerja bagi. Ardana dkk. (2012:156) menyatakan pemberian kompensasi harus berdasarkan pada asas keadilan dan kelayakan. Asas keadilan yaitu besar kecilnya kompensasi harus sesuai dengan jenis kerja, prestasi kerja, resiko pekerjaan tanggung jawab dan jabatan pekerjaan. Asas kelayakan yaitu kompensasi yang diterima oleh karyawan dapat memenuhi kebutuhan dalam tingkat normatis ideal. Tujuan kompensasi yaitu untuk memperoleh sumber daya manusia yang berkualitas, mempertahankan karyawan yang ada, untuk menjamin 
Ni Putu Cindyana Claudia Santoni, Pengaruh Kompensasi...

keadilan, sebagai pernghargaan terhadap perilaku yang diinginkan, mengendalikan biaya, mengikuti aturan hukum, memfasilitasi pengertian serta meningkatkan efisiensi administrasi (Rivai, 2011:359).

Mangkunegara (2008:93) motivasi adalah kondisi yang menggerakkan pegawai agar mampu mencapai tujuan dari motifnya. Hasibuan (2005:92) menyatakan bahwa motivasi penting karena dengan motivasi ini diharapkan setiap individu karyawan mau bekerja keras dan antusias untuk mencapai produktivitas yang tinggi. Motivasi adalah suatu dorongan untuk mencapai sebuah tujuan tertentu yang ditandai dengan sebuah tindakan (Tahira et al., 2013). Motivasi dipengaruhi oleh beberapa faktor yaitu promosi, prestasi kerja, pekerjaan itu sendiri, penghargaan, tanggung jawab, pengakuan dan keberhasilan dalam bekerja (Sunyoto, 2013:13). Menurut Hasibuan (2012:146) pemberian motivasi kepada karyawan tersebut memiliki tujuan yang dapat meningkatkan berbagai hal, yaitu meningkatkan produktivitas kerja karyawan, mempertahankan kestabilan karyawan perusahaan, meningkatkan moral dan kepuasan kerja karyawan, menciptakan suasana dan hubungan kerja yang baik, meningkatkan loyalitas, kreativitas dan partisipasi karyawan, meningkatkan kedisiplinan karyawan, mengefektifkan pengadaan karyawan, meningkatkan tingkat kesejahteraan karyawan, mempertinggi rasa tanggung jawab karyawan terhadap tugas-tugasnya serta meningkatkan efisiensi penggunaan alat-alat dan bahan baku.

Disiplin kerja menurut Sutrisno (2012:89) adalah tingkah laku, perbuatan dan sikap yang sesuai dengan peraturan dari organisasi baik tertulis maupun yang tidak tertulis. Disiplin sangat diperlukan organisasi maupun individu yang 
bersangkutan. Disiplin kerja dirasakan penting, karena jika karyawan tidak disiplin dapat mengganggu kinerja karyawan dan stabilitas organisasi (Gutierrez, 2010). Disiplin kerja dipengaruhi oleh beberapa faktor, yaitu jam kerja, izin karyawan dan absesni karyawan (Mangkunegara, 2004). Simamora (2006) menyatakan disiplin kerja memiliki manfaat bagi organisasi yaitu untuk memastikan perilaku karyawan konsisten sesuai dengan aturan perusahaan, untuk menumbuhkan atau mempertahankan rasa hormat dan saling percaya di antara atasan dan bawahannya, tindakan disipliner dapat pula membantu karyawan untuk menjadi lebih produktif, dengan demikian hal ini menguntungkan dalam jangka waktu yang panjang, serta tindakan disipliner yang efektif dapat memacu individu karyawan untuk meningkatkan prestasi kerja yang baik. Ningrum dan Dhamayanti (2013) menyatakan beberapa indikator disiplin kerja yaitu masuk kerja tepat waktu, mentaati instruksi kerja supervisor, menyelesaikan pekerjaan dengan penuh tanggung jawab, mentaati peraturan yang berlaku dan menghindari konflik.

Kompensasi merupakan suatu imbalan yang diberikan perusahaan atas jasajasa yang telah karyawan berikan dalam menyelesaikan suatu pekerjaan dari perusahaan, dengan kata lain guna untuk membayar waktu yang telah dihabiskan karyawan untuk bekerja dalam organisasi atau perusahaan. Kompensasi berpengaruh secara langsung terhadap produktivitas kerja karyawan (Yamoah, 2013). Berdasarkan penelitian Wardoyo (2015) diperoleh hasil dimana disiplin kerja dan kompensasi signifikan mempengaruhi produktivitas kerja karyawan PT Garuda Milky Artha Surabaya. Peneliti lain Yuliandari dkk. (2014) diperoleh hasil variabel kompensasi berpengaruh positif dan signifikan terhadap produktivitas 
Ni Putu Cindyana Claudia Santoni, Pengaruh Kompensasi...

kerja karyawan bagian loster pada UD. Yuri Desa Pangkung Buluh Kecamatan Melaya Kabupaten Jembrana. Mengacu oleh hal tersebut maka dapat diperoleh hipotesis sebagai berikut :

$\mathrm{H}_{1}$ : Kompensasi berpengaruh positif dan signifikan terhadap Produktivitas Kerja.

Motivasi memiliki peran yang penting di dalam meningkatkan produktivitas kerja karyawan salah satunya dengan memberikan kesempatan bagi karyawan untuk berpartisipasi dalam mengambil keputusan (Khan, 2014). Singh (2014) menyatakan bahwa tingkat motivasi di tempat kerja memiliki pengaruh secara langsung terhadap produktivitas, penelitian membuktikan bahwa seseorang yang termotivasi akan bahagia. Motivasi kerja memliki pengaruh nyata terhadap produktivitas kerja karyawan (Prasetyo, 2016). Hal tersebut menyebabkan produktivitas meningkat, lebih antusias dan mendorong kedisiplinan karyawan. Penelitian ini juga didukung oleh Chukwuma (2014) yang dilakukan di perusahaan manufaktur di Nnewi menemukan pengaruh motivasi positif terhadap produktivitas kerja dan sangat penting bagi organisasi. Putra (2016) menarik kesimpulan dalam penelitiannya bahwa terdapat pengaruh positif signifikan antara motivasi terhadap produktivitas kerja pengrajin perak. Mengacu dari hal tersebut maka dapat diperoleh hipotesis sebagai berikut :

$\mathrm{H}_{2}$ : Motivasi berpengaruh positif dan signifikan terhadap produktivitas kerja.

Disiplin kerja merupakan salah satu faktor yang mempengaruhi produktivitas kerja. Iriani (2010) menyatakan disiplin kerja dibutuhkan agar seluruh aktivitas berjalan dengan mekanismenya. Disiplin kerja adalah variabel yang sangat berpengaruh terhadap produktivitas kerja (Labudo, 2013). Disiplin 
kerja harus ditanamkan dalam diri karyawan sebaiknya bukan atas dasar paksaan dari atasan, tetapi untuk melakukan suatu pekerjaan. Ketidak disiplinan karyawan atau individu dapat memengaruhi produktivitas kerja organisasi perusahaan. Penelitian yang dilakukan oleh Omollo (2015) menyatakan produktivitas kerja yang tinggi di pengaruhi motivasi yang tinggi. Penelitian lain yang dilakukan Rumondor (2013) menemukan bahwa terdapat pengaruh yang positif antara disiplin kerja dengan produktivitas kerja. Ananta (2016) disiplin kerja berpengaruh positif dan signifikan terhadap produktivitas kerja karyawan Villa Mahapala Sanur. Mengacu pada hal tersebut maka di peroleh hipotesis sebagai berikut :

$\mathrm{H}_{3}$ : Disiplin Kerja berpengaruh positif dan signifikan terhadap Produktivitas kerja.

\section{METODE PENELITIAN}

Penelitian ini menggunakan pendekatan kuantitatif yang bersifat asosiatif untuk meneliti data yang bersifat statistik serta menguji suatu hipotesis, dengan kuesioner berbentuk pernyataan sebagai instrumen yang dipakai. Hal ini dikarenakan terdapat hubungan kausal (sebab-akibat) antara variabel bebas $\left(\mathrm{X}_{1} \mathrm{X}_{2}\right.$ $\mathrm{X}_{3}$ ) yaitu kompensasi, motivasi, dan disiplin kerja dengan variabel terikat (Y) yaitu produktivitas kerja.

Penelitian ini dilakukan di Honda Denpasar Agung Bali. Objek pada penelitian ini adalah kompensasi, motivasi, disiplin kerja dan produktivitas kerja. Variabel-variabel yang digunakan dalam penelitian ini yaitu variabel terikat dalam penelitian ini adalah produktivitas kerja (Y) sedangkan variabel bebas dalam penelitian ini adalah kompensasi $\left(\mathrm{X}_{1}\right)$ motivasi $\left(\mathrm{X}_{2}\right)$ dan disiplin kerja $\left(\mathrm{X}_{3}\right)$. 


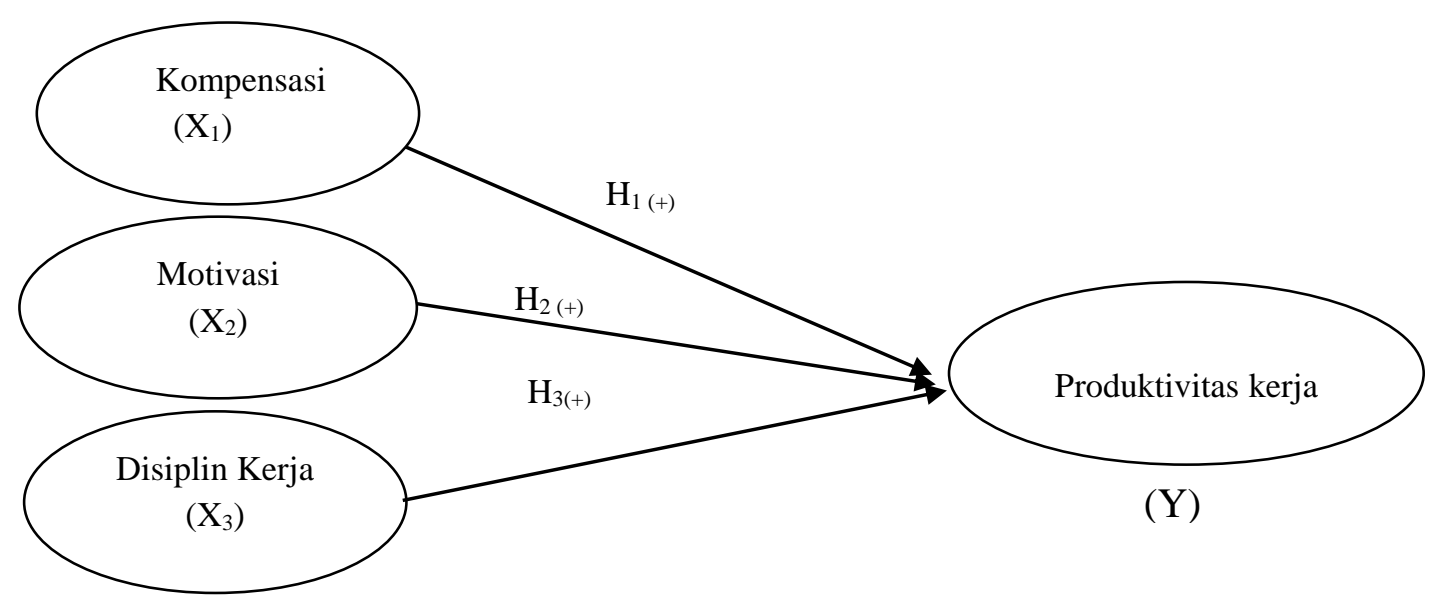

\section{Gambar 1. Model Konseptual Penelitian}

Sumber: Data diolah, 2018

Populasi dalam penelitian ini adalah seluruh karyawan divisi sales di Honda Denpasar Agung yang berjumlah 40 orang karyawan. Sampel yang digunakan adalah teknik sampel jenuh dengan keseluruhan populasi pada Honda Denpasar Agung sebagai responden. Karakteristik sampel yang diambil yaitu berdasarkan jenis kelamin.

Penelitian ini menggunakan metode pengumpulan data wawancara, dan survei melalui penyebaran kuesioner. Penelitian ini menggunakan jenis data kuantitatif dan kualitatif. Data kuantitatif pada penelitian ini adalah data absensi karyawan dan jumlah karyawan yang ada di Honda Denpasar Agung. Kemudian data kualitatif berasal dari sejarah dan gambaran umum Honda Denpasar Agung. Sumber data yang digunakan pada penelitian ini adalah sumber primer dan sekunder. Sumber primer yaitu data berasal secara langsung dari karyawan Honda Denpasar Agung melalui wawancara, dan survei menggunakan kuesioner. Kemudian peneliti menggunakan sumber sekunder yaitu diperoleh dari data perusahaan yang sudah diolah. 
Pengujian instrument pra penelitian yang digunakan yaitu uji validitas dan uji reliabilitas. Uji validitas sering digunakan untuk mengukur ketepatan suatu item kuesioner atau skala, apakah item-item pada kuesioner tersebut sudah tepat dalam mengukur apa yang ingin di ukur sedangkan uji reliabilitas pada penelitian ini menggunakan Cronbach Alpha untuk memeriksa tingkat reliabilitas pada variabel yang berbeda. Uji reliabilitas untuk alternatif jawaban lebih dari dua menggunakan uji cronbach's alpha, yang nilainya akan dibandingkan dengan nilai koefisien reliabilitas minimal yang dapat diterima adalah 0,6 (Umar, 2008:56).

Teknik analisis data yang digunakan yaitu regresi linear berganda dengan Uji koefisiensi (Uji T) dan Uji ANOVA (Uji F). Analisis tersebut digunakan untuk mengetahui hubungan variabel terikat dengan variabel bebas, dapat melihat besar dan arah hubungan tersebut serta mengukur derajat keeratan hubungan antar variabel terikat dengan variabel bebas.

Uji asumsi klasik digunakan untuk menguji data yang akan digunakan memenuhi persyaratan model regresi. Uji asumsi klasik meliputi uji normalitas, uji autokorelasi, uji multikolinieritas, dan uji heteroskedastisitas. Uji regresi simultan (Uji F) gunanya untuk mengetahui pengaruh dari variabel bebas terhadap variabel tak bebas secara bersamasama. Uji statistik $\mathrm{F}$ menunjukkan apakah semua variabel bebas dalam model persamaan memiliki pengaruh secara bersamasama terhadap variabel terikat (Kuncoro, 2001:98). Uji statistik t menunjukkan seberapa jauh pengaruh suatu variabel penjelas secara individual dalam menerangkan variabel terikat. 


\section{HASIL DAN PEMBAHASAN}

Hasil data penelitian yang dilakukan terhadap karyawan Honda Denpasar Agung maka diketahui karakteristik responden yang meliputi empat aspek, yaitu jenis kelamin, usia, masa kerja dan pendidikan terakhir. Jumlah responden yang digunakan dalam penelitian ini yaitu 40 responden.

Tabel 1.

Karakteristik Responden Honda Denpasar Agung Berdasarkan Jenis Kelamin, Usia, Masa Kerja dan Pendidikan Terakhir

\begin{tabular}{|c|c|c|c|c|}
\hline & Keterangan & & $\begin{array}{c}\text { Jumlah } \\
\text { (Orang) }\end{array}$ & Persentase (\%) \\
\hline \multicolumn{5}{|c|}{ Jenis Kelamin } \\
\hline & Laki-Laki & & 28 & 70 \\
\hline \multirow{2}{*}{\multicolumn{2}{|c|}{ Perempuan }} & & 12 & 30 \\
\hline & & Total & 40 & 100 \\
\hline \multicolumn{5}{|l|}{ Usia } \\
\hline & $20-25$ & & 24 & 60 \\
\hline & $26-31$ & & 13 & 32,5 \\
\hline & $31>$ & & 3 & 7,5 \\
\hline & & Total & 40 & 100 \\
\hline \multicolumn{5}{|c|}{ Masa Kerja } \\
\hline 1 tahun & & & 16 & 40 \\
\hline 2 tahun & & & 17 & 42,5 \\
\hline 3 tahun & & & 6 & 15 \\
\hline \multirow{2}{*}{\multicolumn{2}{|c|}{4 tahun }} & & 1 & 2,5 \\
\hline & & Total & 40 & 100 \\
\hline \multicolumn{5}{|c|}{ Tempat Tinggal } \\
\hline SMA & & & 11 & 27,5 \\
\hline Diploma & & & 5 & 12,5 \\
\hline Sarjana & & & 24 & 60 \\
\hline & & Total & 40 & 100 \\
\hline
\end{tabular}

Sumber: Data primer diolah, 2018

\section{Uji Validitas}

Syarat minimum untuk memenuhi nilai validitas jika nilai koefisien korelasinya lebih besar dari 0,3 . Hasil uji validitas instrumen dalam penelitian ini dapat terlihat pada Tabel 2 . 
Tabel 2.

Hasil Uji Validitas

\begin{tabular}{|c|c|c|c|}
\hline Variabel & Item Pernyataan & Pearson Correlation & Keterangan \\
\hline \multirow[t]{2}{*}{ Kompensasi } & $\mathrm{X} 1.1$ & 0,948 & Valid \\
\hline & $\mathrm{X} 1.2$ & 0,941 & Valid \\
\hline \multirow[t]{4}{*}{ (X1) } & $\mathrm{X} 1.3$ & 0,771 & Valid \\
\hline & $\mathrm{X} 1.4$ & 0,944 & Valid \\
\hline & $\mathrm{X} 1.5$ & 0,941 & Valid \\
\hline & X1.6 & 0,859 & Valid \\
\hline \multirow[t]{2}{*}{ Motivasi } & $\mathrm{X} 2.1$ & 0,844 & Valid \\
\hline & $\mathrm{X} 2.2$ & 0,86 & Valid \\
\hline \multirow[t]{8}{*}{ (X2) } & $\mathrm{X} 2.3$ & 0,846 & Valid \\
\hline & $\mathrm{X} 2.4$ & 0,816 & Valid \\
\hline & $\mathrm{X} 2.5$ & 0,819 & Valid \\
\hline & $\mathrm{X} 2.6$ & 0,828 & Valid \\
\hline & $\mathrm{X} 2.7$ & 0,703 & Valid \\
\hline & $\mathrm{X} 2.8$ & 0,701 & Valid \\
\hline & $\mathrm{X} 2.9$ & 0,666 & Valid \\
\hline & $\mathrm{X} 2.10$ & 0,881 & Valid \\
\hline \multirow[t]{2}{*}{ Disiplin Kerja } & $\mathrm{X} 3.1$ & 0,921 & Valid \\
\hline & $\mathrm{X} 3.2$ & 0,82 & Valid \\
\hline \multirow[t]{3}{*}{ (X3) } & $\mathrm{X} 3.3$ & 0,925 & Valid \\
\hline & X3.4 & 0,802 & Valid \\
\hline & $\mathrm{X} 3.5$ & 0,894 & Valid \\
\hline \multirow[t]{2}{*}{ Produktivitas Kerja } & $\mathrm{Y} 1$ & 0,818 & Valid \\
\hline & $\mathrm{Y} 2$ & 0,86 & Valid \\
\hline \multirow[t]{3}{*}{$(\mathbf{Y})$} & Y3 & 0,911 & Valid \\
\hline & Y4 & 0,888 & Valid \\
\hline & Y5 & 0,913 & Valid \\
\hline
\end{tabular}

Sumber: Data primer diolah, 2018

Berdasarkan Tabel 2 diketahui seluruh indikator pernyataan dalam setiap variabel penelitian ini memiliki nilai memiliki pearson correlation atau koefisien korelasi lebih besar dari 0,5 sehingga seluruh indikator tersebut telah memenuhi syarat validitas data. 


\section{Uji Reliabilitas}

Syarat instrumen dikatakan reliabel jika instrumen mempunyai nilai alpha cronbach lebih dari 0,6.

Tabel 3.

Hasil Uji Reliabilitas

\begin{tabular}{clcl}
\hline No. & \multicolumn{1}{c}{ Variabel } & $\begin{array}{c}\text { Cronbach's } \\
\text { Alpha }\end{array}$ & Keterangan \\
\hline 1 & Kompensasi $\left(\mathrm{X}_{1}\right)$ & 0,951 & Reliabel \\
2 & Motivasi $\left(\mathrm{X}_{2}\right)$ & 0,934 & Reliabel \\
3 & Disiplin Kerja $\left(\mathrm{X}_{3}\right)$ & 0,922 & Reliabel \\
4 & Produktivitas kerja $(\mathrm{Y})$ & 0,925 & Reliabel \\
\hline
\end{tabular}

Sumber : Data primer diolah, 2018

Tabel 3 menunjukkan bahwa seluruh instrumen penelitian yaitu kompensasi, motivasi, disiplin kerja, dan produktivitas kerja memiliki nilai Cronbach's Alpha lebih besar dari 0,60 maka semua variabel dalam penelitian ini dapat dikatakan reliabel. Hal ini berarti kuesioner yang digunakan dalam penelitian ini dengan indikator dari variabel penelitian memiliki kondisi yang reliabel.

\section{Deskripsi Variabel Penelitian}

\section{Kompensasi (X1)}

Deskripsi jawaban responden mengenai kompensasi pada tabel 4 yang menunjukkan bahwa rata-rata skor dari 6 pernyataan responden mengenai kompensasi sebesar 3,52. Nilai tersebut berada pada kisaran 3,41-4,20 yang berarti kompensasi yang didapat karyawan Honda Denpasar Agung dalam kondisi yang baik. 
Tabel 4.

Deskripsi Variabel Kompensasi di Honda Denpasar Agung

\begin{tabular}{|c|c|c|c|c|c|c|c|c|}
\hline \multirow{2}{*}{ No } & \multirow{2}{*}{ Pernyataan } & \multicolumn{5}{|c|}{ Proporsi Jawaban Responden } & \multirow{2}{*}{$\begin{array}{l}\text { Rata- } \\
\text { Rata }\end{array}$} & \multirow{2}{*}{ Kriteria } \\
\hline & & STS & TS & $\mathbf{N}$ & $\mathbf{S}$ & SS & & \\
\hline 1 & $\begin{array}{l}\text { Saya menerima gaji setiap } \\
\text { bulan. }\end{array}$ & & 5 & 12 & 17 & 6 & 3,60 & Baik \\
\hline 2 & $\begin{array}{l}\text { Upah yang saya terima sesuai } \\
\text { dengan pekerjaan. }\end{array}$ & 2 & 6 & 9 & 12 & 11 & 3,60 & Baik \\
\hline 3 & $\begin{array}{l}\text { Saya mendapatkan insentif } \\
\text { karena telah menyelesaikan } \\
\text { pekerjaan sesuai target. }\end{array}$ & & 6 & 13 & 12 & 9 & 3,60 & Baik \\
\hline 4 & $\begin{array}{l}\text { Saya mendapatkan fasilitas } \\
\text { yang baik saat bekerja. }\end{array}$ & 2 & 6 & 11 & 12 & 9 & 3,50 & Baik \\
\hline 5 & $\begin{array}{l}\text { Tunjangan yang saya terima } \\
\text { sudah cukup baik. }\end{array}$ & 3 & 7 & 9 & 9 & 12 & 3,50 & Baik \\
\hline 6 & $\begin{array}{l}\text { Jaminan kesehatan yang } \\
\text { diberikan perusahaan telah } \\
\text { sesuai dengan kebutuhan. }\end{array}$ & 3 & 6 & 14 & 9 & 8 & 3,33 & Baik \\
\hline \multicolumn{7}{|c|}{ Kompensasi } & 3,52 & Baik \\
\hline
\end{tabular}

Sumber: Data primer diolah, 2018

\section{Motivasi (X2)}

Tabel 5 menunjukkan bahwa rata-rata skor dari 10 pernyataan diatas mengenai motivasi yaitu sebesar 3,82 berada di kisaran 3,41-4,20 yang artinya baik yang artinya motivasi pada karyawan di Honda Denpasar Agung tergolong dalam kondisi baik.

\section{Disiplin Kerja (X3)}

Tabel 6 menunjukkan bahwa rata-rata skor dari 5 pernyataan diatas mengenai disiplin kerja yaitu sebesar 3,72 berada di kisaran 3,41-4,20 yang artinya baik yang artinya disiplin kerja karyawan di Honda Denpasar Agung tergolong baik. 


\section{Produktivitas Kerja}

Tabel 7 menunjukkan rata-rata skor dari 5 pernyataan diatas mengenai produktivitas kerja yaitu sebesar 3,71 berada dikisaran 3,41-4,20 yang artinya baik. Hal ini menunjukkan bahwa produktivitas kerja karyawan di Honda Denpasar Agung tergolong baik.

Tabel 5.

Deskripsi Variabel Motivasi di Honda Denpasar Agung

\begin{tabular}{|c|c|c|c|c|c|c|c|c|}
\hline \multirow{2}{*}{ No } & \multirow{2}{*}{ Pernyataan } & \multicolumn{5}{|c|}{ Proporsi Jawaban Responden } & \multirow{2}{*}{$\begin{array}{l}\text { Rata- } \\
\text { Rata }\end{array}$} & \multirow{2}{*}{ Kriteria } \\
\hline & & STS & TS & $\mathbf{N}$ & $\mathbf{S}$ & SS & & \\
\hline 1 & $\begin{array}{l}\text { Saya memiliki rasa bertanggung } \\
\text { jawab yang tinggi atas pekerjaan } \\
\text { saya. }\end{array}$ & & 3 & 14 & 12 & 11 & 3.78 & Baik \\
\hline 2 & $\begin{array}{l}\text { Saya pantang menyerah dalam } \\
\text { mencapai suatu target. }\end{array}$ & & 6 & 11 & 12 & 11 & 3,70 & Baik \\
\hline 3 & $\begin{array}{l}\text { Saya menyukai pekerjaan saya } \\
\text { sebagai sales. }\end{array}$ & & 3 & 11 & 11 & 15 & 3,95 & Baik \\
\hline 4 & $\begin{array}{l}\text { Saya menginginkan upah yang } \\
\text { sesuai dengan apa yang saya } \\
\text { kerjakan. }\end{array}$ & & 4 & 11 & 15 & 10 & 3.78 & Baik \\
\hline 5 & $\begin{array}{l}\text { Saya ingin mendapatkan prestasi } \\
\text { di dalam bekerja. }\end{array}$ & & & 14 & 15 & 11 & 3.93 & Baik \\
\hline 6 & $\begin{array}{l}\text { Saya berusaha untuk mengungguli } \\
\text { orang lain dalam bekerja. }\end{array}$ & & 1 & 16 & 17 & 6 & 3,70 & Baik \\
\hline 7 & $\begin{array}{l}\text { Saya senang mendapatkan pujian } \\
\text { atas apa yang saya kerjakan. }\end{array}$ & & 2 & 13 & 15 & 10 & 3,83 & Baik \\
\hline 8 & $\begin{array}{l}\text { Saya menginginkan insetif yang } \\
\text { sesuai dengan apa yang telah saya } \\
\text { kerjakan. }\end{array}$ & & & 13 & 12 & 15 & 4,05 & Baik \\
\hline 9 & $\begin{array}{l}\text { Saya bekerja dengan harapan } \\
\text { mendapatkan perhatian orang lain. }\end{array}$ & 1 & 5 & 15 & 15 & 4 & 3,40 & Baik \\
\hline 10 & $\begin{array}{l}\text { Saya berusaha untuk memenuhi } \\
\text { kebutuhan hidup saya dengan } \\
\text { bekerja. }\end{array}$ & & & 13 & 11 & 16 & 4,08 & Baik \\
\hline & Motivas & & & & & & 3,82 & Baik \\
\hline
\end{tabular}

Sumber : Data primer diolah, 2018 
Tabel 6.

Deskripsi Variabel Disiplin Kerja di Honda Denpasar Agung

\begin{tabular}{|c|c|c|c|c|c|c|c|c|}
\hline \multirow{2}{*}{ No } & \multirow{2}{*}{ Pernyataan } & \multicolumn{5}{|c|}{ Proporsi Jawaban Responden } & \multirow{2}{*}{$\begin{array}{l}\text { Rata- } \\
\text { Rata }\end{array}$} & \multirow{2}{*}{ Kriteria } \\
\hline & & STS & TS & $\mathbf{N}$ & $\mathbf{S}$ & SS & & \\
\hline 1 & $\begin{array}{l}\text { Saya tidak pernah terlambat } \\
\text { masuk kantor. }\end{array}$ & & 7 & 9 & 13 & 11 & 3,70 & Baik \\
\hline 2 & $\begin{array}{l}\text { Perintah yang diberikan oleh } \\
\text { atasan langsung dikerjakan. }\end{array}$ & & 4 & 11 & 16 & 9 & 3,75 & Baik \\
\hline 3 & $\begin{array}{l}\text { Saya menyelesaikan } \\
\text { pekerjaan dengan penuh } \\
\text { tanggung jawab. }\end{array}$ & & 4 & 12 & 13 & 11 & 3.78 & Baik \\
\hline 4 & $\begin{array}{l}\text { Saya menaati peraturan yang } \\
\text { berlaku selama bekerja. }\end{array}$ & & 4 & 10 & 18 & 8 & 3,75 & Baik \\
\hline 5 & $\begin{array}{l}\text { Saya selalu berusaha untuk } \\
\text { menghindari konflik selama } \\
\text { bekerja. }\end{array}$ & & 4 & 14 & 16 & 6 & 3,60 & Baik \\
\hline & Disiplin & Kerja & & & & & 3,72 & Baik \\
\hline
\end{tabular}

Tabel 7.

Deskrispsi Variabel Produktivitas Kerja di Honda Denpasar Agung

\begin{tabular}{|c|c|c|c|c|c|c|c|c|}
\hline \multirow{2}{*}{ No } & \multirow{2}{*}{ Pernyataan } & \multicolumn{5}{|c|}{ Proporsi Jawaban Responden } & \multirow{2}{*}{$\begin{array}{l}\text { Rata- } \\
\text { Rata }\end{array}$} & \multirow{2}{*}{ Kriteria } \\
\hline & & STS & TS & $\mathbf{N}$ & $\mathbf{S}$ & SS & & \\
\hline 1 & $\begin{array}{l}\text { Saya telah mengerjakan } \\
\text { sebagian besar dari total } \\
\text { pekerjaan setiap harinya. }\end{array}$ & & 1 & 12 & 14 & 13 & 3.98 & Baik \\
\hline 2 & $\begin{array}{l}\text { Saya telah menyelesaikan } \\
\text { tugas dengan efisien. }\end{array}$ & & 7 & 10 & 16 & 7 & 3.58 & Baik \\
\hline 3 & $\begin{array}{l}\text { Saya memiliki standar yang } \\
\text { tinggi di dalam menyelesaikan } \\
\text { kerja. }\end{array}$ & & 6 & 12 & 13 & 9 & 3.63 & Baik \\
\hline 4 & $\begin{array}{l}\text { Hasil dari pekerjaan saya } \\
\text { selalu berkualitas. }\end{array}$ & & 4 & 13 & 12 & 11 & 3,75 & Baik \\
\hline \multirow[t]{2}{*}{5} & $\begin{array}{l}\text { Saya selalu mencapai target } \\
\text { yang diberikan dalam tim. }\end{array}$ & & 6 & 13 & 11 & 10 & 3.63 & Baik \\
\hline & Produktivitas Kerja & & & & & & 3.71 & Baik \\
\hline
\end{tabular}

Sumber : Data primer diolah, 2018

Adapun hasil analisis dari masing-masing pengujian asumsi klasik adalah sebagai berikut. 
Tabel 8.

Uji Normalitas

\begin{tabular}{cc}
\hline & Unstandardized Residual \\
\hline $\mathrm{N}$ & 40 \\
Kolmogorov-Smirnov $Z$ & 0,851 \\
Asymp.Sig.(2-tailed) & 0,463 \\
\hline
\end{tabular}

Sumber: Data sekunder diolah, 2018

Tabel 8 menunjukan nilai Kolmogorov-Smirov $Z$ adalah 0,851 dan nilai Asymp.Sig.(2-tailed) adalah 0,463 yang memiliki arti bahwa model persamaan regresi berdistribusi normal karena nilai Asymp.Sig.(2-tailed) 0,463 yang berarti lebih besar dari alpha 0,05 .

Tabel 9.

Uji Multikoleniaritas

\begin{tabular}{lccc}
\hline & Variabel & Tolerance & VIF \\
\hline Kompensasi $\left(\mathrm{X}_{1}\right)$ & 0,410 & 2,439 \\
Motivasi $\left(\mathrm{X}_{2}\right)$ & 0,311 & 3,219 \\
Displin Kerja $\left(\mathrm{X}_{3}\right)$ & 0,480 & 2,083 \\
\hline
\end{tabular}

Sumber: Data sekunder diolah, 2018

Tabel 9 menunjukkan nilai VIF dan tolerance dari variabel kompensasi, motivasi dan disiplin kerja. Masing-masing variabel memiliki nilai tolerence lebih besar dari 10 persen dan nilai VIF lebih kecil dari 10 yang artinya model persamaan regresi bebas dari multikoleniaritas.

Tabel 10.

Uji Heteroskedastisitas

\begin{tabular}{llrrrrr}
\hline Model & \multicolumn{2}{c}{ Unstandardized } \\
Coefficients & \multicolumn{2}{c}{$\begin{array}{c}\text { Standardized } \\
\text { Coefficients }\end{array}$} & & \\
& & B & Std. Error & Beta & \multicolumn{1}{c}{ T } & Sig. \\
\hline 1 & (Constant) & 1.268 & 0,845 & & 1,501 & 0,142 \\
& Kompensasi & 0,027 & 0,040 & 0,169 & 0,674 & 0,504 \\
& Motivasi & $-0,057$ & 0,038 & $-0,437$ & $-1,518$ & 0,138 \\
& Disiplin Kerja & 0,076 & 0,053 & 0,331 & 1,431 & 0,161 \\
\hline
\end{tabular}

Sumber: Data sekunder yang diolah, 2018

Tabel 10 menunjukkan nilai Sig. dari variabel kompensasi, motivasi, dan disiplin kerja masing-masing sebesar 0,504, 0,138, dan 0,161 lebih besar dari 0,05 
yang artinya variabel bebas terhadap absolute residual tidak memiliki pengaruh sehingga model persamaan regresi tidak mengandung gejala heteroskedastisitas.

Analisis regresi linier berganda dalam penelitian ini telah dilakukan dan diperoleh hasil sebagai berikut

Tabel 11.

Hasil Analisis Regresi Linier Berganda

\begin{tabular}{|c|c|c|c|c|c|c|}
\hline & \multirow{2}{*}{\multicolumn{2}{|c|}{ Unstandardized Coefficients }} & \multicolumn{3}{|l|}{ Standardized } \\
\hline \multicolumn{2}{|c|}{ Miodel } & & & \multirow{2}{*}{ Beta } & \multirow{2}{*}{$\mathrm{T}$} & \multirow{2}{*}{$\frac{\text { Sig. }}{.239}$} \\
\hline 1 & (Constant) & $\begin{array}{l}\text { B } \\
-1.572\end{array}$ & $\frac{\text { Std. Error }}{1.313}$ & & & \\
\hline & Kompensasi & .247 & .062 & .347 & 4.003 & .000 \\
\hline & Motivasi & .263 & .059 & .446 & 4.472 & .000 \\
\hline & Disiplin Kerja & .262 & .083 & .254 & 3.174 & .003 \\
\hline & R Square & & & & & 0.889 \\
\hline & F Statistik & & & & & 96.052 \\
\hline & Signifikansi & & & & & 0.000 \\
\hline
\end{tabular}

Sumber: Data sekunder diolah, 2018

Berdasarkan hasil analisis regresi linier berganda yang dapat dilihat pada

Tabel 11, maka persamaan regresi yang digunakan dalam penelitian ini dapat ditulis sebagai berikut:

$$
Y=-1,572+0,247 X_{1}+0,263 X_{2}+0,262 X_{3}+e
$$

Persamaan regresi linear berganda diatas dapat diuraikan sebagai berikut.

$\mathrm{X}_{1}=+0,247$, artinya kompensasi $\left(\mathrm{X}_{1}\right)$ berpengaruh positif terhadap produktivitas kerja (Y) di Honda Denpasar Agung.

$\mathrm{X}_{2}=+0,263$, artinya motivasi $\left(\mathrm{X}_{2}\right)$ berpengaruh positif terhadap produktivitas kerja (Y) di Honda Denpasar Agung.

$\mathrm{X}_{3}=+0,262$, artinya disiplin kerja $\left(\mathrm{X}_{3}\right)$ berpengaruh positif terhadap produktivitas kerja (Y) di Honda Denpasar Agung. 
Ni Putu Cindyana Claudia Santoni, Pengaruh Kompensasi...

$\mathrm{R}^{2}=+0.889$, artinya sebesar 88,9 persen variabel Produktivitas Kerja (Y) dipengaruhi oleh Kompensasi $\left(\mathrm{X}_{1}\right)$, Motivasi $\left(\mathrm{X}_{2}\right)$ dan Disiplin Kerja $\left(\mathrm{X}_{3}\right)$, sedangkan sisanya sebesar 11,1 persen dipengaruhi oleh variabel-variabel lain yang tidak dijelaskan pada penelitian ini.

Berdasarkan hasil analisis pengaruh kompensasi terhadap produktivitas kerja diperoleh nilai Sig. t sebesar 0,000 dengan nilai koefisien beta 0,347. Nilai Sig. t $0,000<0,05$ sehingga $\mathrm{H}_{0}$ ditolak dan $\mathrm{H}_{1}$ diterima. Hasil ini mempunyai arti bahwa terdapat pengaruh positif signifikan antara kompensasi terhadap produktivitas kerja yang berarti apabila kompensasi yang diberikan perusahaan baik maka produktivitas karyawan di Honda Denpasar Agung akan meningkat dan sebaliknya jika kompensasi yang diberikan perusahaan buruk maka produktivitas kerja karyawan di Honda Denpasar Agung akan menurun. Hasil penelitian ini telah sesuai dengan penelitian sebelumnya yang dilakukan oleh Wardoyo (2015) dimana hasil penelitian tersebut kompensasi berpengaruh positif dan signifikan terhadap produktivitas pada PT Garuda Milky Artha Surabaya. Penelitian Yuliandari dkk, (2014) yang dilakukan di UD Yuri Desa Pangkung Buluh Kecamatan Melaya Kabupaten Jembrana menyatakan bahwa terdapat pengaruh positif signifikan antara variabel kompensasi terhadap variabel produktivitas kerja.

Berdasarkan hasil analisis pengaruh motivasi terhadap produktivitas kerja diperoleh nilai Sig. $\mathrm{t}$ sebesar 0,000 dengan nilai koefisien beta 0,466. Nilai Sig. $\mathrm{t}$ $0,000<0,05$ berarti $\mathrm{H}_{0}$ ditolak dan $\mathrm{H}_{1}$ diterima yang artinya motivasi berpengaruh positif signifikan terhadap produktivitas kerja. Semakin tinggi motivasi yang 
diberikan perusahaan kepada karyawan maka produktivitas kerja karyawan di Honda Denpasar Agung akan meningkat, dan sebaliknya apabila perusahaan kurang memberikan motivasi kepada karyawannya maka produktivitas kerja karyawan di Honda Denpasar Agung akan menurun. Penelitian yang dilakukan oleh Ismajli et al. (2015) menjelaskan motivasi berpengaruh positif dan signifikan yang didukung dengan gaji salah satu faktor motivasi yang paling penting. Hasil penelitian ini telah sesuai dengan penelitian yang dilakukan oleh Singh (2014) memperoleh hasil bahwa motivasi berpengaruh positif dan signifikan terhadap produktivitas kerja, penelitian lain yang dilakukan Chukwuma (2014) pada perusahaan manufaktur di Nnewi mendapatkan hasil bahwa motivasi berpengaruh positif terhadap produktivitas kerja. Menurut Penelitian Putra (2016) menarik kesimpulan dalam penelitiannya bahwa terdapat pengaruh positif signifikan antara motivasi terhadap produktivitas kerja pengrajin perak.

Berdasarkan hasil analisis pengaruh disiplin kerja terhadap produktivitas kerja mendapatkan hasil Sig. $\mathrm{t}$ sebesar 0,003 dan nilai koefisien beta 0,254. Nilai Sig. t 0,003 $<0,05$ berarti $\mathrm{H}_{0}$ ditolak dan $\mathrm{H}_{1}$ diterima yang artinya disiplin kerja memiliki pengaruh positif dan signifikan terhadap produktivitas kerja yang berarti semakin tinggi tingkat disiplin karyawan yang bekerja di perusahaan maka produktivitas kerja karyawan di Honda Denpasar Agung akan meningkat, sebaliknya juga apabila tingkat disiplin karyawan rendah maka produktivitas kerja karyawan di Honda Denpasar Agung akan menurun. Hasil penelitian ini sejalan dengan penelitian yang dilakukan oleh Trianto (2010) yang mendapatkan hasil bahwa disiplin kerja memiliki pengaruh positif dan signifikan terhadap 
produktivitas kerja karyawan. Hasil penelitian yang dilakukan oleh Rumondor (2013) menyimpulkan terdapat pengaruh positif antara disiplin kerja dengan produktivitas kerja. Penelitian lain oleh Ananta (2016) disiplin kerja memiliki pengaruh positif dan signifikan terhadap produktivitas kerja karyawan Villa Mahapala Sanur.

\section{SIMPULAN DAN SARAN}

Berdasarkan hasil analisis penelitian maka simpulan yang dapat diambil adalah kompensasi berpengaruh positif dan signifikan terhadap produktivitas kerja karyawan, motivasi berpengaruh positif dan signifikan terhadap produktivitas kerja karyawan dan disiplin kerja berpengaruh positif dan signifikan terhadap produktivitas kerja karyawan.

Beberapa saran yang dapat diberikan adalah a) bagi manajemen harus lebih memperhatikan mengenai kompensasi yang diberikan untuk karyawannya karena kompensasi sangat berpengaruh untuk kemajuan perusahaan nantinya, seperti jaminan kesehatan yang diberikan perusahaan. Perusahaan yang telah memberikan kompensasi yang baik untuk karyawannya diyakini dapat mendorong karyawan untuk bersedia bekerja dengan seluruh kemampuan yang dimiliki atau bekerja lebih produktif lagi untuk kemajuan perusahaan, b) manajemen perusahaan sebaiknya memperhatikan bagaimana cara memberikan motivasi kepada karyawan dalam melaksanakan pekerjaannya, salah satunya dengan memberikan motivasi berupa insentif kepada karyawan agar termotivasi untuk bekerja lebih baik dan giat untuk tetap bekerja memenuhi kebutuhan hidup mereka. Hal ini 
akan meningkatkan produktivitas kerja karyawan yang nantinya berguna untuk kemajuan perusahaan, c) untuk mempertahankan disiplin kerja karyawan maka manajemen harus memperjelas sanksi peraturan yang berlaku serta menegaskan standard operating procedure yang ada agar karyawan dapat menghindari konflik atau masalah pada saat bekerja. Karyawan yang sudah selalu menaati peraturan yang berlaku hendaknya diberikan apresiasi dan memberikan hukuman atau sanksi jika karyawan melanggar aturan yang berlaku. Jika karyawan sudah disiplin dalam bekerja maka karyawan dapat dikatakan produktif dan dapat menyelesaikan tugasnya tanpa masalah.

\section{REFERENSI}

Ananta, I Ketut Febri, I G. A. Dewi Adnyani. 2016. Pengaruh Disiplin Kerja Dan Budaya Organisasi Terhadap Produktivitas Kerja Karyawan Villa Mahapala Sanur-Denpasar. E-Jurnal Manajemen Unud, 5 (2):1103-1130.

Anoraga, Pandji. 2007. Pengantar Bisnis Pengelolaan Bisnis Dalam Era Globalisasi. Jakarta: Rineka Cipta.

Ardana, I Komang, Ni Wayan Muljati, I Wayan Mudiartha. 2012. Manajemen Sumber Daya Manusia. Penerbit Graha Ilmu, Yogyakarta.

Arsyad, Muhammad. 2014. The Importance of Working Discipline to Improve Employee's Working Productivity of Motor Vessel Manufacturing Company in Makassar Shipyard. Journal of business management and strategy, 5(2):196-19.

Chukwuma. Edwin Maduka, Dr Obiefuna Okafor. 2014. Effect of Motivation on Employee Productivity: A Study of Manufacturing Companies in Nnewi. International Journal of Managerial Studies and Research (IJMSR), 2(7).

Dr Khan, M.S., Shalini Gautam. 2014. A Study Of Impact Of Motivation On Productivity Of Employee. The International Journal Of Business \& Management, 2(12): 290-291. 
Elqadri, Zaenal M., Dewi T. W. W., dan Priyono. 2015. The Influence of Motivation and Discipline Work against Employee Work Productivity Tona'an Markets. Review of European Studies, 7(12).

Gomes, Cardoso, Faustino. 2003. Manajemen Sumber Daya Manusia. Yogyakarta: CV.Andi Offset.

Hasibuan, M. 2003. Organisasi dan Motivasi. Jakarta: PT. Bumi Aksara.

Hasibuan, M. 2005. Manajemen Sumber Daya Manusia. Jakarta: PT. Bumi Aksara.

Hanafi, M. H., Ghani K., Arman A. R., dan Shardy A. 2010. Main Factors Influencing Labour Productivity Of The Installation of On-site Prefabricated Components. International Journal Of Academic Research, 2(6): 139-146.

Hasibuan, MelayuSP. 2012. Manajemen Sumber Daya Manusia. Edisi Revisi. Jakarta: Penerbit Bumi Askara.

Hamali, Arif Yusuf. 2013. Pengaruh Motivasi Terhadap Produktivitas Kerja: Studi Kasus Pada PT X Bandung. Journal The WINNERS, 14(2): 77-86

Hanaysha, J. 2016. Testing the Effects of Employee Empowerment, Teamwork, and Employee Training on Employee Productivity in Higher Education Sector. International Journal Of Learning \& Development, 6(1): 165-166.

Huzain, Sadam. 2015. Peran Pimpinan Dalam Meningkatkan Produktivitas Kerja Karyawan Pada PT. Graha Mandala Sakti Bontang. E-Journal Ilmu Pemerintahan, 3(1): 479-493.

Ismajli Naim, Zekiri Jusuf, Qosja Ermira, Krasniqi. 2015. The Importance Of Motivation Factors on Employee Performance in Kosovo Municipalities. Journal of Public Administration and Governance. 5(1): 23-39.

Labudo, Yusritha. 2013. Disiplin Kerja dan Kompensasi Pengaruhnya Terhadap Produktivitas Karyawan. Jurnal EMBA, 1 (3):55-62.

Mangkunegara, AA. Prabu. 2008. Manajemen Sumber Daya Manusia Perusahaan. Bandung: Remaja Rosdakarya.

Mangkunegara, AA. Prabu. 2004. Manajemen Sumber Daya Manusia Perusahaan cetakan pertama. Bandung: Remaja Rosdakarya.

Muammam, Muhyi, Rudy Eko Pramono, Totok Supriyanto. 2013. Hubungan Motivasi Kerja Dengan Produktivitas Kerja Karyawan PT. Yamaha Bintang Motor di Situbondo. 
Ningrum, Endang Widyayanti \& Dhamayanti, Wenny. 2013. Pengaruh Disiplin Kerja, Motivasi Kerja, Upah Kerja Terhadap Produtivitas Kerja di Unit Usaha Jasa Industri dan Aneka Pangan Politeknik Negeri Jember. Jurnal Ilmiah INOVASI, 13(1):1-10.

Nitisemito, A. S. 2000. Personnel Management. Jakarta: Indonesia Gharia

Omollo, Pamela Akinyi. 2015. Effect Of Motivation On Employee Performance Of Commercial Banks In Kenya: A Case Study Of Kenya Comercial Bank In Migori County. Jomo Kenyata University of Agriculture and Technology Kenya. International Journal of Human Resource Studies. 5(2): 87-103.

Prasetyo, Bachtiar Dwi, Harsuko Riniwati. 2016. Influence Of Leadership Style, Motivation And Dicipline To Work Productivity of Department Marine and Fisheries. Economic and Social of Fisheries and Marine Journal, 4(1): 16-27.

Putra, I Made Wijanu, I Komang Wardana. 2016. Pengaruh Motivasi Serta Lingkungan Kerja Terhadap Kepuasan Kerja Serta Dampaknya Terhadap Produktivitas Perjajin Perak. E-Jurnal Manajemen Unud, 5 (12): 25-29.

Rivai, Veithzal \& Ella jauvani Sagala. 2011. Manajemen Sumber Daya Manusia untuk Perusahaan. Teori ke Praktik. Jakarta: PT. Raja Grafindo Persada.

Rumondor, V. W. 2013. Motivasi, Disiplin Kerja dan Kepimpinan Terhadap Produktivitas Kerja Pada Badan Kepegawaian dan Diklat Daerah Minahasa Selatan. Jurnal Emba, 1(4): 1042-1052.

Simamora, Henry. 2004. Manajemen Sumber Daya Manusia. Edisi ketiga. Yogyakarta: YKPN.

Sutrisno, Edy. 2012. Manajemen Sumber Daya Manusia. Jakarta: Kencana Prenada Media Group.

Singh, P. 2014. Increasing Productivity with Motivation in the Workplace National Mounthly Refereed. Journal of Research in Commerce and Management, 2(6):27-32.

Tahira Nazir, Saif-Ur-Rehman Khan, Syed Fida Hussain Shah and Khalid Zaman. 2013. Impact of Rewards and Compensation on Job Statisfaction: Public and Private Universitas of UK. Midle-East Journal of Scientific Research, 14(03):394-403. 
Trianto, Ary, Toto Sugiharto. 2010. Effect Of Compensation, Discipline, And Work Motivation On Employee Productivity Of PT Kukdong International. Journal Faculty Of Economics Gunadarma. 1(4): 1-10.

Wardoyo, Dewi Tri Wijayati. 2015. The Influence of the Discipline and Compensation against Work Productivity (Study on the Security Services Company, PT Garuda Milky Artha Surabaya). International Journal of Business and Management, 11(1).

Wartono, Sis. 2015. Pengaruh Kompensasi, Motivasi Kerja, Disiplin Kerja Terhadap Produktivitas Kerja Karyawan Pada PT Dua Putra Utama Makmur Di Kabupaten Pati.

Yamoah, Emmanuel Erastus. 2013. Relationship Between Compensation And Employee Productivity. Singaporean Journal Of Business Economics And Management Studies, 2(1): 110-114.

Yuliandari, Ni Kadek, I Wayan Bagia, I Wayan Suwendra. 2014. Pengaruh Kompensasi dan Lingkungan Kerja Terhadap Produktivitas Kerja Karyawan Bagian Loster Pada UD Yuri Desa Pangkung Buluh Kecamatan Melaya Kabupaten Jembrana. e-Journal Bisma Universitas Pendidikan Ganesha Jurusan Manajemen. 2(1): 11-12. 